\title{
Foreign Policy and Domestic Politics: a study of the 2002 election in the Republic of Ireland.
}

\author{
John Doyle and Eileen Connolly, \\ Centre for International Studies \\ School of Law and Government \\ Dublin City University ${ }^{1}$
}

Published as: 'Foreign Policy and Domestic Politics: a study of the 2002 election in the Republic of Ireland', Irish Studies in International Affairs, vol. 13: 151-166, $2002 .$.

\begin{abstract}
This article examines the extent to which foreign policy featured in the 2002 general election campaign in the Republic of Ireland. It began with the premise that although foreign policy had not featured prominently in previous elections campaigns the evolving crisis in the peace process in Northern Ireland, coupled with the ongoing debate over the Nice treaty may make foreign policy more likely to be part of the campaign debate and also the subject of party differentiation in 2002. The study reviewed party manifestos, press statements and other aspects of the media campaign. It found clear party differentiation in foreign policy between the parties in their manifestos, however the campaign in the national media was almost devoid of debate on these issues. In analysing the reasons for the absence of debate, the dull and static nature of the campaign is contrasted with the surprising election results. In concludes that although on the surface the absence of engagement on foreign policy in the media appears to concur with the dominant view in the literature that foreign policy in not significant in first order elections inferences can be made that leave the impact of foreign policy on voter behaviour a more open question.
\end{abstract}

\section{INTRODUCTION}

The near consensus in the existing academic literature is that foreign policy issues play a small role in election campaigns and this reflects the elite driven nature of foreign policy formation itself. ${ }^{2}$ The aim of the research on which this article was based was to examine the role of foreign policy in the 2002 general election in the Republic of Ireland and to use the opportunity provided by the policy outlined in the manifestos to discuss party differences on foreign policy.

\footnotetext{
${ }^{1}$ We would like to acknowledge the work of Delma Campbell as research assistant on this project.

${ }^{2}$ See Joseph S. Nye jr., 'The American national interest and global public goods', International Affairs 78 (2) (2002), 233-45 for a good recent article on America in this area and John H. Aldrich, John L. Sullivan and Eugene Borgida, 'Foreign Affairs and Issue Voting: Do Presidential Candidates "Waltz Before a Blind Audience?", American Political Science Review 83 (1) (1989), 123-42 for an excellent introduction to the literature.
} 
Prior to the election campaign there were a number of key foreign policy issues which were the subject of public debate and appeared to be matters of concern to the voting public, notably Ireland's relationship with the EU in the wake of the rejection of the Nice Treaty, the government's fractious relationship with the European Commission on economic issues and the contentious decision to join Partnership for Peace. In addition the peace process in Northern Ireland was drifting towards crisis and Sinn Féin the largest nationalist party in the Northern Ireland since 2001 was fielding candidates in the Southern election with the hope of making significant gains. These factors seemed to indicate before the campaign that foreign policy issues would form the basis of party differentiation and competition and might be ones on which the opposition parties could attack the government. Certain features of the 2002 election campaign particularly those relating to the campaign strategies of the main parties and the role of the media coupled with the, in some ways, surprising outcome made the relationship between foreign policy and domestic pressures more difficult to judge than had been expected but it also raised questions about the role of foreign policy in party competition more generally.

\section{FOREIGN POLICY AND ELECTION CAMPAIGNS}

The relationship between domestic pressures and foreign policy has been an almost perennial debate in the study of international relations and one where most scholars can agree that inter-connections exist, but it is the precise impact and the direction of causation that are disputed. In the modern era James Rosenau sought to generate research leading to a better understanding of 'national-international linkages' ${ }^{3}$ and later Nye and Keohane ${ }^{4}$ brought this issue to the centre of the debate on international relations. Robert Putnam's (1988) conclusion still has resonance, when he said

It is fruitless to debate whether domestic politics really determine international relations or the reverse. The answer to that question is clearly 'Both, sometimes'. The more interesting questions are 'When?' and 'How?'

This exhortation has been followed by other writers. Steven Hook has argued that non-state actors both domestic and international are 'increasingly potent' in foreign policy adaptation and have 'elevated the importance of state-society

\footnotetext{
${ }^{3}$ James Rosenau, Linkage Politics: Essays on the Convergence of National and International Systems. (New York, 1969).

${ }^{4}$ e.g. in Power and Interdependence (Boston, 1977).

${ }^{5}$ Robert Putnam, 'Diplomacy and Domestic Politics: The Logic of Two Level Games', International Organisation 42 (3) (1988), 427-60: 427.
} 
relations ${ }^{6}$ while US political science has in recent years sought to model the specific linkages between form of domestic politics and international action. ${ }^{7}$

An important subset of this debate has been the extent to which election campaigns have been influenced by foreign policy questions - questions set by either the prevailing international climate or by strong voter preferences at the domestic level. This literature has, to date, been dominated by American political science. In the US, studies from the 1950s onwards tended to suggest that the US public had quite low levels of knowledge of foreign policy. ${ }^{8}$ While there have been countervailing arguments, both the 'common sense' perception and the majority of academic analyses suggest that despite the USA's hegemonic status the domestic public is not strongly motivated by foreign policy issues. Recently Joseph Nye argued that the American public paid little attention to international affairs and that foreign policy played a marginal role in the 2000 US elections. In these circumstances according to Nye the 'battle fields of foreign policy are left to those with special interests'. ${ }^{9}$ This emphasis in the literature has been challenged from within the US by authors such as Aldrich, who argues that political elites can mobilise voters using foreign policy agendas. ${ }^{10}$ Indeed it could be argued that this is precisely what the Clinton campaign did, with regard to Northern Ireland policy and Irish-American voters in the US presidential elections in 1992 and 1996. ${ }^{11}$ However, whatever the specifics of US elections and foreign policy, the question needs to be raised as to whether the dominance of US based research has given the international debate a bias which does not necessarily reflect Irish or indeed European experience.

Nye's analysis would appear to be supported by an analysis of the reports on general elections in western European democracies (11 in all), published in Electoral Studies from 1997 to 2002. This indicates that while party positions on foreign policy are generally discussed by the authors, in particular divergent views on European integration and European Monetary Union, it is not viewed as being a significant campaign issue. Dissension within political parties and sensitivity to post-election coalition arrangements were among the factors constraining parties from turning these differences into election issues. Exceptions were Norway, where the debate about European integration influenced the outcome of the 1997 election and Portugal also in 1997, when the crisis in East Timor coincided with an election campaign. An 'expert survey' on policy positions of British political parties in 1997 demonstrated that although

\footnotetext{
${ }^{6}$ Steven W. Hook (ed.), Comparative Foreign Policy: adaptation strategies of the Great and Emerging Powers (New Jersey, 2002), 3.

7 See Alastair Smith, 'International Crisis and Domestic Politics', American Political Science Review 92 (3) (1998), 623-38; Kenneth A. Schultz, 'Domestic Opposition and Signalling in International Crisis', American Political Science Review 92 (4) (1998), 82944.

${ }^{8}$ See Gabriel A. Almond, The American People and Foreign Policy (New York, 1950); James N. Rosenau (ed.) Public Opinion and Foreign Policy (New York, 1961).

${ }^{9}$ Nye 'The American national interest and global public goods': 233-4.

${ }^{10}$ Aldrich et al., 'Foreign Affairs and Issue Voting'.

${ }^{11}$ See Conor O'Cleary, The Greening of the White House (Dublin, 1996).
} 
policy on Europe is among the top two policy dimensions for every party, foreign policy was attributed a relatively low overall salience in elections by those surveyed. ${ }^{12}$ These finding could be interpreted as supporting the view that while foreign policy may be significant for parties it is not significant in elections or it could reflect academics own bias as a result of the development of consensus within the discipline. Evidence from Switzerland suggests that when referenda on foreign policy issues are considered a different picture is presented. Marquis and Sciarini look at four foreign policy referenda at the federal level between 1981 and 1995 - on the UN, the Bretton Woods institutions, the European Economic Area and the creation of a Swiss UN peacekeeping corps - and compare them to the domestic policy votes. ${ }^{13}$ They found that voters were "well informed about and active in foreign policy" in contrast to the findings in the US literature. ${ }^{14}$

To assess how expert opinion has analysed the role of foreign policy in general elections in the Republic of Ireland from 1987 the Annual Reviews of Foreign Policy in Irish Studies in International Affairs for the relevant years, the series of books How Ireland Voted 1987, 1989, 1992 and 1997, and the articles on each general election in Irish Political Studies from 1987 onwards, were surveyed. In line with the survey of Electoral Studies the consistent feature of this literature is that foreign policy issues are described as a point of differentiation in the party programmes and manifestos, but rarely feature in the analysis of voter concerns or of party competition. There was little discussion of the relationship between public opinion on foreign policy issues and voter behaviour or party strategies. It has been assumed, rather than argued, that Irish parties do not use foreign policy as a campaign tactic and that even if Northern Ireland is occasionally raised, it is not important in explaining voter decisions. (The question of whether Northern Ireland policy should be included in a study of 'foreign policy' is one of the unusual aspects of the Irish case. Institutionally officials in both the Dept of An Taoiseach and the Department of Foreign Affairs work on the policy development and are engaged in negotiations. In deference to both nationalist and non-nationalist the foreign/domestic aspects of Northern Ireland policy have always been fudged. For the purposes of this analysis it will be included as foreign policy rather than be consigned to the half way house of 'Anglo-Irish' relations.)

The 1987 Irish general election is an instance where Northern Ireland policy was a feature of the election campaign arising from the clear divisions that existed on the 1985 Anglo-Irish Agreement. The significance of this debate has however been minimised by commentators. Also in the background of this election were divisions on the Single European Act evident in the Dáil debate the previous

\footnotetext{
${ }^{12}$ Michael Laver, 'Party Policy in Britain 1997: Results from an Expert Survey', Political Studies XLVI (2) (1998), 336-49.

${ }^{13}$ Lionel Marquis and Pascal Sciarini, 'Opinion formation in foreign policy: the Swiss experience', Electoral Studies 18 (1999): 453-71.

${ }^{14}$ Ibid: 467
} 
December and the on-going 'Crotty' Court challenge to the Government's decision to seek to ratify the related Treaty without a referendum. ${ }^{15}$ Keatinge's argues that "while quite a wide range of foreign policy issues were raised and there were some differences of emphasis between the parties, in general there was little attempt to move beyond simple assertions". ${ }^{16}$ Likewise the analysis of party competition in the 1987 election by Peter Mair largely ignores foreign policy dimensions including European ones ${ }^{17}$ and Anglo-Irish relations only gets a brief mention in a section headed 'traditionalism versus pluralism' dealing with Northern Ireland, family law and religion.

In the aftermath of the 1985 Anglo-Irish Agreement most voters viewed the development positively and Fianna Fáil's opposition to it left them open to challenge. ${ }^{18}$ Initially, Charles Haughey refused to become involved in a debate on the Northern Ireland question, using the traditional argument that it should not be made an election issue. Fine Gael was also constrained by having to avoid the accusation of playing party politics with a vital national interest, and indeed with people's lives. However, in the last ten days of the campaign, as Fine Gael lost ground in the polls, Fine Gael, the Labour Party and the Progressive Democrats simultaneously made an issue both of Fianna Fáil's alleged ambiguity in relation to the Anglo-Irish Agreement and of potential problems for Anglo-Irish relations that could be created if Charles Haughey were Taoiseach. ${ }^{19}$. This attack appeared to successfully place Mr. Haughey on the defensive and Fianna Fáil at a disadvantage. In spite of this Girvin argues that the Anglo-Irish Agreement does not appear to have been "salient" with voters. ${ }^{20}$ Likewise Keatinge argues that although the emergence of the northern issue coincided with an erosion of Fianna Fáil's standing in opinion polls, and that while "policy may have been the currency of political debate...it does not seem to have been the deciding factor for most voters". ${ }^{21}$ Keatinge states that other foreign policy questions were "virtually invisible" and concludes that the final result of the election seems to confirm the orthodox view of voters' relative indifference to foreign policy. This conclusion can be questioned. According to Laver $15 \%$ of the voters in a close run election that led to a minority government saw policy on the Anglo-Irish Agreement as 'very important' to them in an MRBI//rish Times

\footnotetext{
${ }^{15}$ Patrick Keatinge, 'Ireland's Foreign Relations in 1987', Irish Studies in International Affairs, 2 (4) (1988), 77-104: 81-85.

${ }^{16}$ Keatinge, ibid: $78-80$.

${ }^{17}$ Peter Mair, 'Policy Competition' in Michael Laver, Peter Mair and Richard Sinnott (eds.) How Ireland Voted: the general election of 1987 (Dublin, 1987), 30-47.

${ }^{18} \mathrm{An} \mathrm{MRBI}$ poll conducted for the Irish Times in the week after the Agreement was signed saw $59 \%$ approval for the Agreement but perhaps more importantly $43 \%$ of Fianna Fáil voters approved and only $52 \%$ of FF voters support the Haughey position. Interestingly given Dick Spring's prominent association with the Agreement, $22 \%$ of Labour voters supported Haughey stance. Poll reproduced in Irish Political Studies 1 (1987), 144.

${ }^{19}$ Brian Girvin, 'The Campaign', in Michael Laver, Peter Mair and Richard Sinnott (eds.), How Ireland voted: the general election of 1987 (Dublin, 1989), 9-29.

${ }^{20}$ Girvin, ibid: 29.

${ }^{21}$ Patrick Keatinge, 'Ireland's Foreign Relations in 1987': 78-80.
} 
poll. ${ }^{22}$ While there was no exit poll to confirm the impact of the opposition's campaign tactic of attacking Fianna Fáil and Charles Haughey in particular on their Northern Ireland policy the progress of the opinion polls and the final outcome of the election suggests that it may have eroded Fianna Fáil support.

There is no reference to foreign policy for the 1989 general election in Irish Political Studies, or in Farrell's or Girvin's chapters in How Ireland Voted 1989. ${ }^{23}$ Marsh and Sinnott also in How Ireland Voted note that under 3\% of voters saw issues related to Northern Ireland policy as important issues in the election campaign $^{24}$ and despite the referendum on the Single European Act EU in May 1987, issues or foreign policy did not feature at all. A key feature appears to have been that in contrast to 1987 there was no determined effort by the larger parties to raise these issues. Keatinge says "foreign policy issues barely featured" in the general election campaign though they were present in the party manifestos. ${ }^{25}$ Since the 1987 election Fianna Fáil has changed their position on the Anglo-Irish Agreement and had sought to use its provisions to seek further reform in Northern Ireland. This had the effect of substantially removing this issue from the campaign. In contrast to 1987, there was no perceived advantage to be gained by any of the parties in raising Northern Ireland as a prominent campaign issue and so it remained in the margins. While Labour, the Workers Party and Sinn Féin raised neutrality the larger parties did not respond in a manner which allowed a debate. A content analysis of campaign coverage in two national newspapers identifies fifteen issue categories, including a "miscellaneous" heading. Foreign policy does not feature as an issue, but Northern Ireland does. Coverage on the latter, measured in column centimetres, represented one per cent of total in the Irish Independent and four per cent of total in the Irish Times. ${ }^{26}$

In the 1992 election Girvin noted that the main differences between the parties came "at the margin, on issues, such as Northern Ireland"27. Different attitudes to the questions of articles 2 and 3 of the Irish Constitution were evident, particularly between the former coalition partners, Fianna Fáil and the Progressive Democrats. Fine Gael and the Democratic Left supported the

\footnotetext{
${ }^{22}$ Michael Laver, 'Issues, attitudes and party policy', in Michael Laver, Peter Mair and Richard Sinnott (eds.), How Ireland voted: the general election of 1987 (Dublin, 1989), 113-26: p.117 (based on MRBI/Irish Times poll.

${ }^{23}$ Pat Neville, 'The 1989 general election in the Republic of Ireland', Irish Political Studies 5, (1990), 69-76; Brian Girvin, 'The Campaign', 5-22 and David M. Farrell 'Campaign Strategies and media coverage', 23-43, both in Michael Gallagher and Richard Sinnott (eds.), How Ireland Voted 1989 (Galway 1990).

${ }^{24}$ Michael March and Richard Sinnott, 'How the Voters Decided' in Michael Gallagher and Richard Sinnott (eds.) How Ireland Voted 1989 (Galway, 1990), 94-130: 108.

${ }^{25}$ Patrick Keatinge, 'Annual Review: Ireland's Foreign Relations in 1989', Irish Studies in International Affairs, 3 (2) (1990), 137-165: 138.

${ }^{26}$ David Farrell, 'Campaign strategies and media coverage', in Michael Gallagher and Richard Sinnott (eds.) How Ireland Voted 1989 (Galway, 1990), 23-43: 40.

${ }^{27}$ Brian Girvin, 'The road to the election' in Michael Gallagher and Laver, Michael (eds.), How Ireland Voted 1992. (Dublin, 1993), 1-20: 16.
} 
Progressive Democrats' view that Fianna Fáil was guilty of a lack of generosity and flexibility in the negotiations. Democratic Left went furthest in suggesting that the amendment of the article should be offered at an early rather than a late stage in any future talks. In an MRBI poll taken just after Albert Reynolds became Taoiseach in 1992 80\% of respondents identified Northern Ireland as a priority for his Government (compared to $99 \%$ for unemployment and $70 \%$ for the EU) ${ }^{28}$ However debate on Northern Ireland during the campaign never reached the levels of 1987, as neither the political parties or the media sought to make it an issue.

According to Rees in the 1997 general election, "Irish foreign policy and Ireland's overseas interests were not pressing electoral issues in the run up to the June election". ${ }^{29}$ An analysis of the 1997 Irish party manifestos by the Manifesto Research Group, cited by Garry and Mansergh places external relations among three low priority domains, at an average 6.3 percent of content. There was however significant variation within the individual parties, with the Green Party at 11.2 per cent and Fine Gael at 2.6 per cent. Much of the foreign policy content related to the EU, with the Greens and the Progressive Democrats emphasising negative rather than positive aspects of the EU. The Greens, Democratic Left and Labour devoted 2 percent to positive mentions of internationalism, a category that encompassed issues such as aid for the developing world and support for the UN. ${ }^{30}$ The issue of European security and neutrality featured in most manifestos. Partnership for Peace (PfP) was regarded positively by the Labour Party, Fine Gael and the Progressive Democrats. Fine Gael suggested a referendum would be required. The Progressive Democrats advocated closer military co-operation with European partners, while Sinn Féin, Democratic Left, Fianna Fáil and the Greens opposed membership of the PfP. Despite the clear policy divergences there was very little focus on these issues in the party campaigns.

Northern Ireland featured significantly in the election for the first time since 1987. Opinion polls early in the year had signalled this - presumably due to the ongoing peace process - between $10 \%$ and $11 \%$ of all voters thought Northern Ireland would be the main issue in the forthcoming election. ${ }^{31}$ Murphy notes that Northern Ireland was one of a number of points of contention between the potential Fianna-Fail-Progressive Democrat coalition. ${ }^{32}$ The day before the Dáil was dissolved, Bertie Ahern met the Sinn Féin leader Gerry Adams, and indicated his belief that the British and Irish governments should meet Sinn Féin

\footnotetext{
${ }^{28}$ Cited in Michael Marsh and Richard Sinnott, 'The Voters Stability and Change' in Michael Gallagher and Michael Laver (eds.) How Ireland Voted 1992 (Dublin, 1993), 93-114: 99.

${ }^{29}$ Nicholas Rees 'Ireland's foreign relations in 1997', Irish Studies in International Affairs 9 (1998), 135-59:136.

${ }^{30}$ John Garry and Mansergh, Lucy, 'Party Manifestos' in Michael Marsh and Paul Mitchell (eds.), How Ireland Voted 1997, (Oxford, 1999), 82-106.

${ }_{31}^{31}$ MRBI poll from the Irish Times, repeated in Irish Political Studies 13 (1998): 239-40.

32 Gary Murphy, 'The 1997 General Election in the Republic of Ireland', Irish Political Studies 13 (1998), 127-134: 128.
} 
before the IRA cease-fire was renewed. Fine Gael and Labour opposed government-Sinn Féin contact without a cease-fire. Democratic Left, the Greens and the Progressive democrats wanted a cease-fire as a precondition for Sinn Féin entry into talks. The Progressive Democrats stated that Mary Harney would not meet Adams, and nor should the governments. The following day, however, "to much incredulity among commentators", the Progressive Democrats denied that there was much difference between the parties. ${ }^{33}$ There was also disagreement between the parties in the outgoing government. Before the British election of 1 May, the outgoing Taoiseach John Bruton had declared that a vote for Sinn Féin in advance of an IRA cease-fire would be a vote for violence. In a speech in Derry on 26 May, Labour Tánaiste Dick Spring was reported as saying that the Sinn Féin vote in the election was a vote for peace. Following a charge from the opposition that the government was sending out conflicting signals, the two claimed to be in agreement that Sinn Féin could turn its electoral mandate into a vote for peace. Later in the campaign, this issue surfaced again, when Bertie Ahern attacked Bruton for his failure to give leadership to nationalist Ireland. Gerry Adams also entered the fray and accused the Taoiseach of mismanaging the peace process. ${ }^{34}$ Marsh and Sinnott highlight the impact of Northern Ireland in the 1997 election in an analysis of opinion polls. They found that 'if a voter spontaneously mentioned Northern Ireland as a factor influencing his or her vote, he or she was substantially more likely to vote for Fianna Fáil in preference to any other party save Sinn Féin'. The negative impact on the government parties (Fine Gael, Labour Democratic Left) was they say 'quite substantial'. ${ }^{35}$ It seems that Fianna Fáil had successfully convinced the electoral that they rather than Fine Gael could best manage the peace process.

The dominant view among Irish academics is that foreign policy issues (including Northern Ireland policy) are not significant factors in influencing voters' decisions. Studies of election campaigns tend to either ignore foreign policy altogether; note that it is a issue of party differentiation but argue it is not one of significance for voters; or treat it as an issue of media interest which has little impact on the public. A model of foreign policy based on elite independence and public indifference would seem to be re-enforced. However there are indications that when in 1987 and 1997, parties chose to make Northern Ireland a campaigning issue the clear divergence between the parties benefited Fine Gael in 1987 and Fianna Fáil in 1997. In both cases the party with the perceived advantage used considerable resources to drive its advantage home. Differences in party policy are clearly a necessary condition for this type of intervention but not sufficient. In most elections there has been differences in party policy but in 1987 and 1997 major political parties chose to make them a campaigning issue in their media work, advertising etc. When parties made this decision to campaign actively there is prime facie evidence that the public did respond. Certainly Northern

\footnotetext{
${ }^{33}$ Murphy, ibid: 128.

${ }^{34}$ Murphy, ibid: 130.

${ }^{35}$ Michael March and Richard Sinnott 'The Behaviour of the Irish Voter' in Michael Marsh and Paul Mitchell (eds.), How Ireland Voted 1997, (Oxford, 199) 151-80: 174.
} 
Ireland policy at least has had the capacity in some circumstances to influence voter behaviour. Also by its nature focusing on election campaigns implies a focus on party competition - competition for the floating voter. This does not preclude foreign policy being a key factor in party identification and the retention of core voters.

\section{THE 2002 ELECTION}

\section{Manifestos}

A study of the foreign policy content of election manifestos needs to be grounded in a clear understanding of the current function of party manifestos in Ireland, in particular the long manifestos issued to the media, but not generally circulated, which were surveyed for this study. These manifestos serve a number of purposes, they are amongst the most worked out statement of policy issued by the political parties and in this context they include policy commitments in areas that the party chooses not to highlight during an election campaign - some aspects of foreign policy may well fit into this category. Foreign policy issues are included because they are part of the party's self image; of concern to its core support or perhaps only to a small segment of that support; of importance as part of internal party coalition building or support building among interest groups. In Ireland since the late 1980s manifestos have also played an increasing role as draft programmes for government, including in some cases a level of detail that is unlikely to be of interest to the general public. As multi-party governments have become the norm since 1989 parties enter the election with the assumption, even hope, that they will need to negotiate a detailed programme for government in a very short period after the election result is known. The Progressive Democrats as a policy driven party were perceived to have had a strong influence on the programme for government of the Fianna Fáil/Progressive Democrats coalition 1989-92, this influenced the Labour party strategy in 1992 when it produced an election manifesto with a view to developing a coalition programme for government, a negotiated position they were able to take into the 1994 Rainbow government. For these reasons manifestos have significance beyond the immediate election campaign.

It is not the intention of this section to give a detailed summary of the manifestos foreign policy coverage, it will rather highlight the relative importance given to foreign policy and discuss the purpose which engagement with foreign policy served for the parties. Of the two government parties Fianna Fáil's foreign policy was the most extensive and the most persuasive in the sense that they sounded like a party intending to govern. The manifesto, A Lot Done More To Do, contained 86 pages of which 11 closely typed pages were devoted to foreign policy, the content of which was specific and detailed. In comparison the Progressive Democrats' engagement with foreign policy including Anglo-Irish relations was perfunctory - surprisingly so given that Liz O Donnell has been a 
very effective minister of state in the Department of Foreign Affairs. As the major opposition party, Fine Gael's manifesto was disappointingly vague and compared to the Fianna Fáil manifesto relatively brief with only seven pages of well spaced print given to foreign policy. Furthermore unlike Fianna Fáil who had highlighted Northern Ireland and other foreign policy issues in their introduction and summary sections Fine Gael gave these issues less prominence. In the summary introduction to the manifesto by Michael Noonan there is no reference to Northern Ireland or Anglo-Irish relations. There are however generalised references to 'an Ireland that keeps its commitment within the rules of the EU ... that champions the cause of countries less well-off than ourselves ... that stands up for our belief in a peaceful and just world order'.

All of the left of centre parties used foreign policy to some extent to bolster their left wing or alternative credentials. The Labour Party, in spite of being the largest in this bloc was the least energetic in this regard and did not really seek to distinguish itself from the conservative parties using foreign policy. Their manifesto was primarily focused on their campaign pledges which were confined to domestic policy issues and it was released in stages so that the section on 'Ireland and the World', released last and with no major media effort received little attention. This section of the manifesto was not even referred to in the manifesto launch press release on Labour's web-site. The entire document had to be opened to learn of its existence. Labour's focus on its domestic policy pledges may have been motivated by a perceived necessity to lay the ground for post-election bargaining which it thought was inevitable with one of the two big parties. In addition however, unlike the other left parties it had not opposed the Nice Treaty, so in competition with the Greens and Sinn Féin it would not have been strategic to draw undue attention to its support for a second referendum. Labour does however give support to the European Social Model and increased development aid and calls for a referendum on neutrality.

Sinn Féin and the Green Party used their manifestos to detail their more radical policies and both parties devoted a good deal of space to these issues. They both support increased development aid and in terms of EU policy oppose a second Nice referendum, 'enhanced co-operation', increased majority voting and the Rapid Reaction Force. The Green Party manifesto not surprisingly highlights international action on environmental issues including Sellafield and Climate Change. Sinn Féin, in spite of the difficulties which the arrest in Columbia of people associated with the party caused with its American support base, maintained its support for a number of radical causes in clear opposition to the US administration. For example they call for the implementation of UN resolution 242 in the Middle East, the ending of sanctions on Iraq and the US embargo on Cuba, the cancellation of third world debt and the introduction of the Tobin Tax.

In their manifestos all parties cover Northern Ireland and Anglo-Irish relations. Fianna Fáil and Sinn Féin give it most prominence, with both parties clearly feeling that their respective roles in the peace process would be positively 
perceived by the electorate. It was a very prominent part of the Fianna Fáil manifesto, reflecting their view of this as a 'feel good' story and also their determination to retain their nationalist credentials in the face of competition from Sinn Féin. Fianna Fáil emphasised and set out detailed proposals on crossborder co-operation. Sinn Féin in turn called for a Green paper on Irish unity and for some form of northern representation in the Oireachtas. In keeping with the low priority given to foreign affairs more generally the focus of the Progressive Democrats' Northern Ireland section contains an attack on Sinn Féin for its alleged lack of support for the Irish Defence Forces and for their failure to join the police board in Northern Ireland. The Fine Gael manifesto while different in tone to the position adopted by John Bruton when party leader was still clearly distinguishable from Fianna Fáil's. There was little attention given to crossborder co-operation and it emphasised British-Irish than North-South relations. It highlights that 'priority will be given to the decommissioning of all paramilitary arms', and reaffirms the centrality of opposition to violence and the unionist guarantee.

On Europe the key issues of party difference were attitudes to the Nice Treaty, neutrality and Ireland's role in future European Security and Defence policy. Despite the government's public row with the EU Commission on economic and tax policy ${ }^{36}$ the Fianna Fáil manifesto strongly supported the EU and European issues are given prominence. The Progressive Democrats are also supportive of the EU but emphasise their insistence that fiscal and taxation decisions remain national and not European ones. Fine Gael in the manifestos section on Europe unlike that on Northern Ireland engaged in strong criticism of the outgoing Fianna Fáil-Progressive Democrats government. They attack the Government parties for destroying Ireland's positive image within the EU; by allowing Ministers to speak critically; by delays in implementing directives; and by poor Ministerial attendance at some Council meetings. Fine Gael also call for a debate on neutrality without setting out their own view, a failure to spell out the detail of their policy proposals that is repeated on other issues. Crucially despite the critical tone the party did not choose to use this issue strongly in their media campaign and in debate with Fianna Fáil. The Labour Party set out a series of Irish and EU level reforms highlighting increased transparency within Europe and oversight of EU measures in Ireland. They will seek a EU declaration on neutrality, and try to enact legislation to limit Ireland's participation in the European Rapid Reaction Force to 'peace-keeping and peace enforcement missions which have UN legitimacy'. They would finally seek to insert a prohibition on Ireland entering a mutual defence pact into the constitution no later than the date of a second referendum on Nice which they believe should be held. Finally as stated above the Greens and Sinn Féin's policy positions on the EU oppose the current direction of EU integration and in particular oppose the Rapid Reaction Force and a second referendum on Nice.

${ }^{36}$ See Irish Times, 12 February 2001. 
There is therefore clear party differentiation on the EU. Fine Gael is the most strongly pro-EU in its rhetoric and criticises Fianna Fáil for being too negative. Fianna Fáil's manifesto is however very positive on European integration and enlargement and there is no hint of the earlier clashes between McCreevy and the EU Commission or the euro sceptical comments from leading members of Fianna Fáil. ${ }^{37}$ The Progressive Democrats are positive but assertive on low taxation and fiscal autonomy. Labour are positive while emphasising the need for reforms on the democratic deficit and clarification on neutrality. The Greens and Sinn Féin while supportive of enlargement are clearly opposed to the Nice Treaty, to any security or defence policy and to the current institutional reforms.

There was a series of other issues raised in the manifestos. Fianna Fáil and Labour had sections on Defence, all parties had commitments to at least $0.7 \%$ of GNP being spent on official development aid. Fine Gael criticises the campaign to secure election to the UN Security Council as being 'expensive and time wasting'. The Greens and Labour highlight the need to review industries in Ireland making equipment for the arms trade. Sinn Féin also mention UN reform and Third World debt. However none of these issue was consistently mentioned by all the parties in a manner which enables comparisons. Of the 'stand alone' issues only 'Sellafield' featured in the media campaign.

\section{THE CAMPAIGN ISSUES}

Apart from party manifestos it is possible to make some judgements as to the relative priority given to foreign policy issues by the campaign fought by each of the parties. However parties do not campaign in a vacuum. Small parties have only a limited capacity to set agendas and where media coverage and time is proportional can find themselves squeezed out even of the debates initiated by the larger parties. Larger parties can also find it difficult to generate debate in the media if none of the other parties choose to compete with them on that particular issue and the media can influence party responses by what activities and topics it chooses to cover.

A survey of all archived press releases on the web-sites of the political parties from May $1^{\text {st }}$ to the election day of May $17^{\text {th }}$ indicated a lower priority for foreign policy than was evident in the manifesto coverage. ${ }^{38}$ Of a total of 88 press releases from Fianna Fáil, four related to foreign policy issues, one was on Sellafield, and three on Northern Ireland, including one policy document. Fine Gael's site hosted 124 press releases of which seven related to foreign policy: two on Sellafield, one on the Middle-East crisis, one on Northern Ireland and three on Europe. Of 88 press releases from the Labour party, just one related to

\footnotetext{
${ }^{37}$ For example those by Minister Síle DeValera, Irish Times $19^{\text {th }}$ September 2000.

${ }^{38}$ Archived Press releases were available for all of the parties only for the last three-weeks of the campaign, it was decided for the sake of comparability to use this shorter period rather than the full election campaign.
} 
foreign policy on the issue of Sellafield and there was no media campaign on the foreign policy section of their manifesto. Sinn Féin's web-site archived a total of 66 press releases, of which four had a foreign policy content, of these, three related to Northern Ireland and one to Sellafield. The Green Party site had nine releases in the period under review, none of which was related to foreign policy. ${ }^{39}$ The Progressive Democrats' web-site held 62 press releases, of which one was foreign policy related, on the question of Europe. ${ }^{40}$ Overall therefore foreign policy issues, including Northern Ireland made up only a small proportion of what the parties chose to release to the media in formal press releases in the final three weeks of the campaign but some of the parties did seek to use other high profile tactics to mobilise support especially on Northern Ireland and to a lesser extent on Europe.

$\mathrm{NI}$ as a campaign issue

Fianna Fáil clearly sought to promote their involvement in the peace process to maximum effect. Their pre-election billboard advertising focused on the economy and the Good Friday Agreement in roughly equal proportions. Their manifesto strongly highlighted their role in the peace process. "Peace Prosperity Progress" was one of two slogans used on their election posters and leaflets. Bertie Ahern's opening comments on the TV debate with Michael Noonan ${ }^{41}$ and his final speech of the campaign focused heavily indeed almost exclusively on Northern Ireland. It is clear that Fianna Fáil believed that their approach to the peace process had gained them a crucial advantage with floating voters compared to Fine Gael. Fianna Fáil hoped to benefit from the peace process in 2002 as they had done in 1997, using their role in the signing of the $1998 \mathrm{Good}$ Friday Agreement as a 'feel good' factor in their campaign and seeking to portray themselves as better placed to consolidate the Agreement than their electoral rivals. Fianna Fáil saw Sinn Féin as a much more significant electoral threat than they had been previously especially in key constituencies. A high profile on Northern Ireland and a strong commitment to North-South links was probably designed to hold (and attract) more nationalist minded voters.

In this election, unlike 1997, Fine Gael managed to prevent Northern Ireland becoming a topic of debate in the campaign. Michael Noonan in his campaign for the Fine Gael leadership had promised to bring Fine Gael back to the nationalist centre and move away from what many within Fine Gael perceived to be the unpopular stance taken by John Bruton. ${ }^{42}$ This was supported by other leading members of the party. At their party conference in February 2002 Deputy

\footnotetext{
${ }^{39}$ The Green Party had issued a press release on Sellafield on April 19.

${ }^{40}$ In fact the same statement, by Michael McDowell, was issued twice (13 and 15 May) under the respective titles of "Why is nobody mentioning Europe?", and "Election will decide Ireland's interest in Europe". Available from http://www.progressivedemocrats.ie, accessed on 03/05/02.

${ }^{41}$ RTE One television 9.30pm on $14^{\text {th }}$ May 2002

${ }^{42}$ Bruton had as Fine Gael leader consistently argued that the role of the Irish Government was to be equidistant between northern nationalists and unionists rather that part of the nationalist consensus at the heart of the peace process. He repeated this view after the election, Irish Times, 21 May 2002.
} 
Leader Jim Mitchell referred to the party's 'undiluted commitment to peace and reconciliation in our quest for national unity, which remains our first policy objective'. Party spokesperson on Northern Ireland, Jimmy Deenihan said Fine Gael was an 'unashamedly nationalist party'. The party however did not seek to campaign on this issue because of Fianna Fáil's perceived advantage in this area. It simply wished to close the debate and deny Fianna Fáil the chance of making electoral capital. Therefore the differences in the manifestos were not used in the campaign debates to attack Fianna Fáil. Instead Michael Noonan made a virtue of restraint and in a statement, referred to a long-standing Fine Gael practice, whether in government or opposition, of making only one statement on Northern Ireland during general election campaigns. He went on to say that while the electorate is entitled to know where Fine Gael stands, it is also important "that we do not complicate an already difficult situation by introducing it as an element in party politics in this jurisdiction". ${ }^{43}$ While Fine Gael chose to intervene much more forcefully on Northern Ireland in 1987 and again in 1997, in 2002 they clearly saw that a debate on Northern Ireland would serve to benefit Fianna Fáil and sought to prevent Fianna Fáil making it a point of policy difference between the parties. It is interesting to note that in the Ahern-Noonan television debate of May $14^{\text {th }}$ the four minutes out of seventy which were dedicated to Northern Ireland were remarkable for their consensual tone. ${ }^{44}$ It was the one exchange of the evening where Noonan made no attempt to counter Ahern or to critique Fianna Fáil policy.

The Labour Party also chose not to raise Northern Ireland as part of its election campaign. The party had made a number of attacks on Sinn Féin, on Northern Ireland policy loosely defined, in the run up to the election, most strikingly on the Adams-Quinn television debate on the Late Late Show when Ruairí Quinn tried to minimise the Sinn Féin leader's role in the peace process. ${ }^{45}$ These attacks continued until mid April ${ }^{46}$ but were not a feature of the national Labour Party campaign after that date. It must be assumed that the Labour Party, like Fine Gael, felt that raising the issue and engaging in debate with Sinn Féin would be counter-productive, more likely to rebound in Sinn Féin's favour. Michael McDowell of the Progressive Democrats also attacked Sinn Féin on the issue of their alleged lack of support for the Gardai and Defence Forces. While this form of attack on Sinn Féin featured to some extent in the pre-campaign debates, once Sinn Féin President Gerry Adams made a statement explicitly recognising the Defence Forces and the Gardai as the legitimate military and police forces of the state it ceased to be a significant issue. The Green Party made no significant interventions on Northern Ireland or Anglo-Irish relations.

\footnotetext{
${ }^{43}$ Michael Noonan. Fine Gael, Statement on Northern Ireland, 12 May 2002. Available from: http://www.finegael.ie, accessed on 03/05/02/

${ }^{44}$ Tonight with Vincent Browne, RTE, May 14.

${ }^{45}$ Report of show in Irish Times, 17 November 2001.

${ }^{46}$ e.g. statement from Ruairí Quinn, $19^{\text {th }}$ April 2002 on Labour website. Mark Hennessy of the Irish Times notes a similar change of tone in Kerry North, Irish Times $4^{\text {th }}$ May 2002.
} 
Sinn Féin in their campaign literature explicitly asked for an endorsement of their role in the peace process. The language of their speeches and leaflets was seeking support to continue and strengthened the process and was not an explicit attack on the policies of other parties. In their overall campaign strategy they seem to have taken the view that they had already mobilised that section of the population who were going to vote for them primarily on the basis of the national question. They, therefore, sought to use the opportunity of the election to broaden their appeal and highlight their commitment to social justice and equality issues. Their campaign slogan "Building an Ireland of Equals", while capable of including equality in Northern Ireland and the concept of a united Ireland also directly focused on issues of poverty and social exclusion. At their campaign launch, while they highlighted the peace process (and the Nice Treaty) they particularly focused on the widening gap between rich and poor that had developed under the previous Fianna Fáil and Fine Gael led governments and sought to present the party as unmistakably to the left on economic policy. ${ }^{47}$

Despite the best efforts of Fianna Fáil Northern Ireland did not feature as a significant issue in the actual campaign primarily because Fine Gael did not compete for support on this basis. Sinn Féin as a small party could not make the North and election issue even if it had chosen to. What is noticeable is that the other parties did not choose to attack Sinn Féin on its Northern Ireland policy in a concerted way during the campaign. The strongest criticism of Sinn Féin, based on denying its legitimacy as a political party, had taken place prior to the campaign proper.

\section{Europe}

The defeat of the EU 'Nice' Treaty referendum might have set the stage for a significant debate on the future of Europe or even on the Treaty itself in the general election. However no such debate took place. In this case it was the anti-Nice parties Sinn Féin and the Greens which sought to put the question of a second referendum, neutrality and European security and the wider issue of the future of the $\mathrm{EU}$, on the agenda for debate. However apart from manifesto commitments to a second referendum in the autumn the pro-Nice parties would not enter this debate during the election campaign. The Irish Times editorialised the day before polling saying it was a 'great paradox' that the Nice Treaty was not discussed during the campaign. On that day they also carried two separate articles on Nice and an opinion poll. They did not reflect however on their own role in shaping the election coverage. Similarly the Kerryman newspaper, without self-reflection, editorialised on the absence of 'key political issues', including the Nice Treaty from the election debate.

Interventions by the pro-Nice parties were limited. John Bruton hosted one press conference for Fine Gael. He accused Fianna Fáil and the Progressive Democrats of failing in their duty to promote ratification of the Treaty in a second

\footnotetext{
${ }^{47}$ See Irish Times $8^{\text {th }}$ May 2002. The two headlines on the launch were 'SF plans higher taxes for rich and businesses' and 'Party lays out surprisingly detailed left-wing vision'.
} 
referendum and attacked Finance Minister Charlie McCreevy for his public rows with the EU Commission on the question of Irish budgetary and taxation policy. Labour raised the reform of CAP as part of their agriculture policy document but in the context of benefiting small over large farmers rather than overall EU level reform. Apart from this their interventions were limited to a statement from MEP Prionsíos de Rossa saying 'Ireland must be at the heart of Europe' re-iterating the positions set out in their manifesto but not directly engaging with the positions of the other parties. ${ }^{48}$

Sinn Féin and the Greens clearly wished to engage in a debate on the EU. They both raised it at their campaign launches, issued press releases on Nice and mentioned in on most of their election leaflets. However with the effective refusal of the pro-Nice parties to join in the debate and given the nature of TV and media coverage discussed below they failed to make much impact in the media on this issue, though voters could hardly have been unaware of their positions. It is not possible to say to what extent opposition to the Nice Treaty and the profile they gained in the earlier referendum contributed to the relative success of the Greens and Sinn Féin in the election. The tiny Socialist Party who opposed Nice retained their sitting TD and some independent candidates such as Finian McGrath in Dublin North Central, who though elected primarily as local activists, had campaigned very publicly in their own constituencies for a no vote in the Nice referendum, also did well. ${ }^{49}$

There was some other media coverage of foreign policy issues during the campaign that did not relate directly to the election. Most parties issued statements on the Middle East for example. However the releases/speeches were statements of principle which did not attack or engage with other Irish political parties. They probably would have been issued whether there was an election on at that time or not and were only tangentially part of the election campaign. ${ }^{50}$

One feature of the foreign policy aspects of the election campaign was the absence of any significant NGO lobbying or interventions. The activity of Irish based NGOs with a foreign policy focus in lobbying generally, in particular with the Department of Foreign Affairs and the Oireachtas Committee on Foreign Affairs has been documented. ${ }^{51}$ Yet during the heightened political activity of the election across a range of NGOs there was no concerted effort to secure policy

\footnotetext{
${ }^{48}$ Issued 30 April 2002, see www.labour.ie

${ }^{49}$ McGrath, though elected primarily as an independent community candidate had a strong track record of involvement in nationalist and human right campaigns related to Northern Ireland, such as the campaign or the release of the 'Birmingham Six' and in support of nationalist communities opposing controversial Orange Order marches.

${ }^{50}$ e.g. Michael D Higgins on 'Israel's military campaign in the Occupied Territories', $14^{\text {th }}$ April 2002 (Labour website). Brian Cowen supporting a UN inquiry into events in Jenin, $19^{\text {th }}$ April, Irish Times $20^{\text {th }}$ April 2002.

${ }^{51}$ e.g. Ben Tonra 'Irish Foreign Policy' in William Crotty and David E. Schmitt (eds.) Ireland on the World Stage (Harlow, 2002), 24-45.
} 
commitments from the political parties or highlight issues of concern ${ }^{52}$. There was no previous study to compare level of NGO activity in other elections but anecdotal evidence from party activists suggests that there was a lower level of NGO lobbying in 2002. It is possible that the increased engagement between NGO's, the Department of Foreign Affairs and the Oireachtas Committee has drawn lobby groups into a more a structured relationship with the policy process so that they no long give the same priority to enlisting public support during election campaigns.

\section{MEDIA COVERAGE}

In the media analysis that followed the election a view was widely expressed that the election campaign had been largely devoid of content and debate. ${ }^{53}$ This was perceived to be in stark contrast to the election results, where the comparatively strong showing of Sinn Féin, the Greens and the independents, coupled with the substantial loss of seats by Fine Gael, indicated that something was going on among the electorate that had not been visible in the media coverage of the campaign. ${ }^{54}$ The blame for this failure to identify and discuss what was motivating the electorate focused on the overcautious stage-managed campaigns of the major parties and the acquiescence of the media to the agenda set by party strategists and pollsters. The media coverage acted like a piecrust, obscuring and containing the interesting shifts in opinion and voting intention that were taking place across the country.

The dominance of television coverage in the media campaign has meant that not only is it the public's primary source of information but that it also sets the tone for coverage in other media. RTE rigidly allocated TV time in proportion to the percentage support received at the previous election. This decision ignored the substantial fall in Fine Gael support - tracked in opinion polls over a lengthy period and the rise in support for Sinn Féin and the Greens. It also meant that independent candidates and the outgoing Socialist Party TD who could have contributed to the debate were effectively excluded. The television coverage followed a particular format, relying heavily on coverage of party leaders canvassing, opinion polls and debates on economic statistics. The style of TV "analysis" was also overwhelmingly adversarial rather than investigative, in that it chose to high light arguments between the parties rather that instigate discussion on party policy from an independent perspective. Therefore in most cases debate on policy issues only took place where the main parties decided they wanted to engage on the issue. Since the pro Nice parties saw no advantage to them in campaigning actively on the Treaty - there was no debate on the issues involved in the ratification of the treaty in the campaign.

\footnotetext{
${ }^{52}$ Eilís Ní Leathlobhair , The Political Engagement of NGOs in Ireland during the 2002 election unpublished MA thesis, Dublin City University 2002.

53 e.g. Terry Prone, Irish Times, May 162002.

${ }^{54}$ Harry Browne, Irish Times, May 252002.
} 
Obviously foreign policy is not the only issue which was lost from the campaign because of this type of coverage. Issues higher on the public's political agenda such as health policy were only discussed at a superficial level. The key point from the foreign policy perspective is that the expected low level of foreign policy engagement was further depressed by the particular characteristics of the 2002 campaign. In spite of significant differences between the parties and the expectation that voters would, at least at the margins, be motivated by those issues of difference, the main political parties for tactical reasons and with the acquiescence of the media were able to successfully prevent debate. An argument could be made that the key issues of difference between the parties Northern Ireland, the Nice Treaty, neutrality and engagement in peace keeping if debated would have been more likely to gain publicity and enhance the electoral performance of the smaller parties. In addition to this tactical reason for avoiding debate, the main parties also wished to avoid issues that would disadvantage them vis a vis each other. The actual outcome of the election however leaves open the question of the role that foreign policy plays in the construction of party image and the attraction and retention of voters.

\section{CONCLUSION}

The results of this study are in line with previous assessments of the role of foreign policy in general elections in that the debate on foreign policy issues was absent from the campaign, and it is not on this basis possible to assign any significance to inter party policy differences on these issues to the outcome of the election. But it does not necessarily follow from this that in fact foreign policy positions do not have any impact on party support. There is a case to be made that in 1987 and again in 1997 policy differences on Northern Ireland between Fine Gael and Fianna Fáil had a marginal but significant impact on the final election result. Certainly in the 2002 election the strategies of the parties would indict that they believed foreign policy issues could have an impact on their support even if it was a marginal one. This point is made by inference - Fianna Fáil assumed its Northern Ireland policy was an electoral advantage by the prominence it was given in publicity material and Fine Gael by their avoidance of the topic evidently thought so too. All the pro-Nice Treaty parties implicitly recognised the electoral danger of engaging in debate on this topic and therefore avoided it.

Aldrich et. al. looking at US presidential elections examined the apparent contradiction between the amount of time and effort devoted to foreign policy by candidates and the prevailing scholarly opinion that voters have little information and weak interest on these issues and therefore they do not impact on voting behaviour. ${ }^{55}$ They conclude that voters do have opinions on these issues and do

${ }^{55}$ John H. Aldrich, John L. Sullivan and Eugene Borgida, 'Foreign Affairs and Issue Voting: Do Presidential Candidates "Waltz Before a Blind Audience?", American Political Science Review 83 (1) (1989), 123-42. 
appreciate party difference and that if the candidates seek to do so they can activate voters on foreign policy. In the Irish case, because the main parties avoided any foreign policy debate (with the exception of Fianna Fáil on Northern Ireland) does not mean that voters do not understand party differences on foreign policy or that the possibility of motivating voters on this issue is non-existent. At present the role of the foreign policy profiles of the Green Party, Sinn Féin and some of the independents in their election success is an unknown quantity. Given they now form a significant minority in the Dáil and there are some interesting foreign policy debates ahead it may mean that foreign policy debates could be more significant in the next election. 